\title{
Airborne PCDD/F profiles in rural and urban areas of Buenos Aires Province, Argentina
}

\author{
N. Cappelletti ${ }^{\mathrm{a}, \mathrm{b}, *}$, M. Astoviza ${ }^{\mathrm{a}, \mathrm{b}}$, M.C. Migoya ${ }^{\mathrm{a}, \mathrm{b}}$, J.C. Colombo ${ }^{\mathrm{a}, \mathrm{c}}$

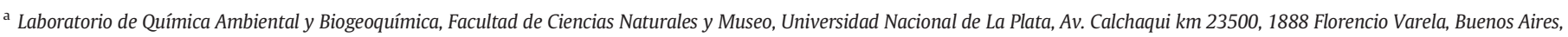 \\ Argentina \\ b Consejo Nacional de Investigaciones Científicas y Técnicas, Argentina \\ c Comisión de Investigaciones Científicas, Provincia de Buenos Aires, Argentina
}

\section{H I G H L I G H T S}

- Atmospheric PCDD/Fs concentrations were determined in atmosphere a range of urban agglomerations in $\mathrm{Ar}$ gentina

- PCDD/Fs concentrations in rural and small towns are greater than an order of magnitude less than urbanized area

- PCDD/F profiles are influenced by diesel, industrial, and open burning emissions
G R A P H I C A L A B S T R A C T

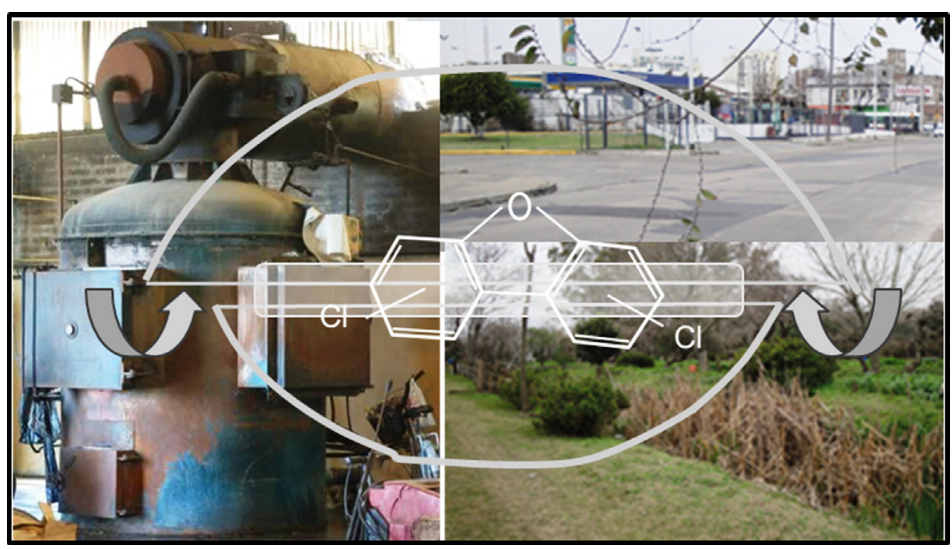

\section{A R T I C L E I N F O}

\section{Article history:}

Received 31 May 2016

Received in revised form 16 July 2016

Accepted 17 July 2016

Available online $\mathrm{xxxx}$

Editor: D. Barcelo

\section{Keywords:}

Polychlorinated dibenzo-p-dioxin

Polychlorinated-dibenzofuran

Passive air samplers

Buenos Aires

\begin{abstract}
A B S T R A C T
Passive air samplers were deployed in 18 rural and urban locations in the densely populated Buenos Aires district to investigate airborne polychlorinated dibenzo-p-dioxin and polychlorinated-dibenzofuran ( $\mathrm{PCDD} / \mathrm{Fs}$ ) profiles, sources and spatial patterns. Atmospheric concentrations reported as total toxic equivalents (TEQs), 2378substituted $\left(\sum_{17} \mathrm{PCDD} / \mathrm{F}\right)$ and $4-8$ homologous groups $\left(\sum_{4-8} \mathrm{PCDD} / \mathrm{F}\right)$ were highly variable and significantly correlated to urban scale. The rural average $\left(3.0 \pm 2.7 \mathrm{fg} \mathrm{TEQ}^{-3}\right)$ was thirty times less than metropolitan values $\left(90 \pm 51 \mathrm{fg} \mathrm{TEQ}^{-3}\right)$, with urban cluster $\left(5.4 \pm 4.0 \mathrm{fg} \mathrm{TEQ}^{-3}\right)$ and urbanized area $\left(33 \pm 50 \mathrm{fg} \mathrm{TEQ}^{-3}\right)$ in an intermediate position. A rural outlier exhibited the highest TEQ values (295-296 fg TEQ $\mathrm{m}^{-3}$ ) suggesting a local source. Principal component analyses (PCA) performed for $\sum_{17} \mathrm{PCDD} / \mathrm{F}$ and $\sum_{4-8} \mathrm{PCDD} / \mathrm{F}$ to identify source contributions showed more significant results for homologue groups compared to 17 congeners ( 83 and $45 \%$ of total variability explained, respectively) pointing to dominant diesel emissions enriched in TeCDF in rural areas, and open burning and industrial sources characterized by TeCDD, PeCDD contributing most in urbanized and metropolitan areas. Homologue group PCA also performed better clustering samples according to sources and TEQ
\end{abstract}

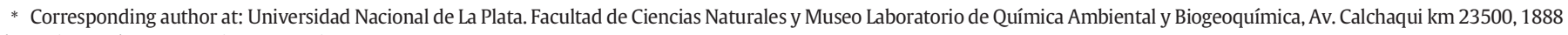
Florencio Varela, Buenos Aires, Argentina.
}

E-mail address: ncappelletti.laqab@gmail.com (N. Cappelletti). 
concentrations. The PCDD/Fs profile of the rural outlier dominated by HxCDF and HpCDD/F showed a typical municipal incineration signature confirming the presence of local source.

(C) 2016 Published by Elsevier B.V.

\section{Introduction}

Polychlorinated dibenzo-p-dioxins and polychlorinated-dibenzofurans (PCDD/Fs) are persistent organic pollutants (POPs) unintentionally formed as by products in many industrial activities and combustion processes globally distributed in the environment (Hites, 2011). The most toxic seventeen $2378 \mathrm{PCDD} / \mathrm{F}$ congeners containing 4 to 8 chlorines have received considerable public and scientific attention, and a toxic equivalent scheme (TEQs) has been developed to assess health risks and overall toxicity of complex mixtures (Van den Berg et al., 1998).

The global biogeochemical cycle of PCDD/F is principally controlled by atmospheric emissions, depletion reactions (e.g. $\mathrm{OH}$ radical destruction) and transport to terrestrial and aquatic ecosystems through dry and wet deposition (Lohmann et al., 2006). Thus, atmospheric assessment of PCDD/F is a first very relevant step for monitoring surveys, especially in South America where this information is very scarce. In this context, passive air samplers (PAS) are alternative low-cost and lowmaintenance sampling devices for semi-quantitative measurement of POPs in air that have been adopted by Stockholm Convection (UNEP, 2011). In a worldwide PAS air monitoring study, Bogdal et al. (2013) reported a wide range of concentrations for Latin America (9$678 \mathrm{fg}^{\mathrm{TEQ}} \mathrm{m}^{-3}$ ), with the highest concentration found in Peru. A more conservative range $\left(0.9-30 \mathrm{fg} \mathrm{TEQ}^{-3}\right)$ has been recently reported for Latin America and Caribbean by the Global Monitoring Network (Schuster et al., 2015). Comparable concentrations have been reported for an urban area of Manizales, Colombia (18-39 $\mathrm{fg} \mathrm{TEQ}^{-3}$ ), where the industrial use of coal has been identified as the main PCDD/F source (Cortés et al., 2014). There is little information available for South American megacities, i.e. for San Pablo, Brazil with 17 million inhabitants, active sampling combining gas and particulate phases revealed high concentrations (47-753 fg TEQ m ${ }^{-3}$; De Assunção et al., 2005), whereas more recent PAS study yielded lower concentrations (20-30 fg TEQ $\mathrm{m}^{-3}$; Schuster et al., 2015).

In Argentina, the province of Buenos Aires $\left(\sim 300,000 \mathrm{~km}^{2}\right)$ includes $\sim 40 \%$ of the population and $36 \%$ of gross production of the country with an important industrial sector (petrochemical, iron and steel, automotive) and a vast development of agriculture and livestock (12,000 km²; Ministerio de Economía, 2012). Buenos Aires Metropolitan area ( 13 million inhabitants; $\left.4000 \mathrm{~km}^{2}\right)$ includes the autonomous capital city of Buenos Aires and densely populated adjacent municipalities, constituting the second largest urban agglomeration in South America and the largest populated area in Argentina, yet there are no comprehensive air PCDD/F measurements in this region.

In this study we report atmospheric PCDD/F concentrations and compositional patterns in rural, urban and industrial sites of Buenos Aires province to assess the overall status of air quality and evaluate the relationship between population size and atmospheric PCDD/F concentrations. A comparative assessment of 17 congeners and homologue groups by principal component analysis (PCA) is performed to explore the overall variability of the data and elucidate principal sources.

\section{Methods}

\subsection{Passive air samplers}

Passive air samplers (PAS) were designed and constructed at the Environmental Chemistry and Biogeochemistry Laboratory (LAQAB, La Plata National University) based upon those used at RECETOX (Research Centre for Toxic Compounds in the Environment, Masaryk University,
Czech Republic) and Environment Canada (EC). Briefly, they consist of polyurethane foam disks (PUF; $14 \mathrm{~cm}$ diameter; $1.5 \mathrm{~cm}$ thick; $385 \mathrm{~cm}^{2}$ surface area; $0.03 \mathrm{~g} \mathrm{~cm}^{-3}$ density) housed in two stainless steel domes (external diameters of 24.5 and $22.5 \mathrm{~cm}$ ) separated by a $2 \mathrm{~cm}$ gap. The performance of this design was compared with the devices employed by RECETOX and EC (Klanova et al., 2006; Harner et al., 2006). Regression analysis performed between the total mass captured by LAQAB device compared with the other samplers (LAQAB vs. RECETOX-LAQAB vs. EC) showed strong correlation $\left(\mathrm{R}^{2}\right)$ for PCBs (0.97-0.98), PAHs (0.94-0.92) and Organochlorine Pesticides (0.940.66 ), indicating no significant differences between samplers (t Student test, $\alpha=0.05$; Astoviza et al., 2016).

PUFs were rinsed with tap and deionized water, air dried, Soxhlet extracted for $24 \mathrm{~h}$ with acetone: petroleum ether (1:1), dried and finally wrapped with solvent cleaned aluminum foil until deployment. To assess site-specific sampling rates, depuration compounds were added prior deployment (10 ng each of PCBs 30, 119 y 207; Absolute Standard Inc.) in washed and solvent rinsed sampling chambers.

In general, samplers were placed 3-4 $\mathrm{m}$ above the ground on street lights or trees in public or private lands (yacht clubs, fishing/sport clubs, private houses/farms). At rural sites PAS were placed at variable distances (200-1000 m) from farmlands. After the sampling period PUF disks were removed using solvent-rinsed tongs, wrapped in aluminum foil and stored at $-10{ }^{\circ} \mathrm{C}$ until extraction.

Sampling rates $\left(\mathrm{R} ; \mathrm{m}^{3} \mathrm{~d}^{-1}\right)$ were calculated according to passive air sampling theory (Pozo et al., 2004), based on the amount of depuration compounds retained by PUFs after sampling. Concentrations were calculated as mass of PCDD/F in each PUF over volume (volume $=$ $\mathrm{R} \times$ sampling time). Meteorological conditions and $\mathrm{R}$ values are detailed in Supplementary material, Table S2.

\subsection{Sampling sites}

PAS were deployed at 18 different sampling locations during 34 months. Two sampling campaigns were conducted in cold (May 2012 to October 2012) and warm season (October 2012 to April 2013) with a duplicated deployment in the most populated site, totalizing 38 samples. Sampling sites were classified as rural ( $\mathrm{R} ;<5000$ inhabitants), urban cluster (UC; 5000 to 50,000 inhabitants), urbanized area (UA; 50,000 to 500,000 inhabitants) and metropolitan area (M; $>500,000$ inhabitants) according to United States Census Bureau scheme (United States Census Bureau, 2010). Additional site information is presented in Table 1 and Fig. 1. To make a more precise comparison between urban scale and atmospheric PCDD/F concentration, population was calculated within a $25-\mathrm{km}$-diameter circle centered on the sampling location using the Gridded Population of the World, Version 3 (Center for International Earth Science Information Network; GPWv3). All population estimates were reviewed and double-checked using online census data.

\subsection{Analytical methods}

PCDD/Fs were extracted following the 1613 EPA method (US EPA, 1994). Briefly, samples, laboratory blanks and field blanks were spiked with $13 C_{12}$ PCDD/F recovery standard (LCS 1613; Wellington Laboratories Inc.) and Soxhlet-extracted with petroleum ether for $24 \mathrm{~h}$. The extracts were reduced to $3 \mathrm{~mL}$ under nitrogen and fractionated on successive chromatography on silica gel and silica gel-charcoal columns (Molina et al., 2000). The PCDD/F fraction was evaporated to a volume 
Table 1

Sampling site information and airborne PCDD/F concentrations in each sampling period (cold/warm).

\begin{tabular}{|c|c|c|c|c|c|c|c|c|}
\hline Station & Code & Coordinates & Inhabitants & Main activity & Class & $\underline{\Sigma_{4-8} \mathrm{PCDD} / \mathrm{F}}$ & $\frac{\Sigma_{17} \mathrm{PCDD} / \mathrm{F}}{\mathrm{fg} \mathrm{m}^{-3}}$ & TEQ \\
\hline Patagones & $\mathrm{Pa}$ & S $39^{\circ} 59^{\prime} 43^{\prime \prime} \mathrm{W} 63^{\circ} 22^{\prime} 55^{\prime \prime}$ & 2000 & A & Rural & $137 / 1549$ & $37 / 12$ & $5.0 / 1.44$ \\
\hline Saladillo & Sa & S $35^{\circ} 36^{\prime} 30^{\prime \prime}$ W $59^{\circ} 50^{\prime} 14^{\prime \prime}$ & 2084 & A & Rural & $473 / 260$ & $19 / 6.0$ & $1.3 / 0.71$ \\
\hline Ines Indart & I & S $34^{\circ} 24^{\prime} 24^{\prime \prime}$ W $60^{\circ} 32^{\prime} 18^{\prime \prime}$ & 1000 & A & Rural & NA/139 & NA/11 & $\mathrm{NA} / 1.29$ \\
\hline Bolivar & Bo & S $36^{\circ} 23^{\prime} 38^{\prime \prime} \mathrm{W} 61^{\circ} 08^{\prime} 30^{\prime \prime}$ & 4540 & A & Rural & NA/778 & $\mathrm{NA} / 12$ & $\mathrm{NA} / 1.44$ \\
\hline 30 de Agosto 1 & TA1 & S $36^{\circ} 11^{\prime} 57^{\prime \prime} \mathrm{W} 62^{\circ} 33^{\prime} 08^{\prime \prime}$ & 4777 & A & Rural & $2214 / 561$ & $476 / 70$ & $3.9 / 4.1$ \\
\hline 30 de Agosto 2 & TA2 & $\mathrm{S} 36^{\circ} 16^{\prime} 38^{\prime \prime} \mathrm{W} 62^{\circ} 32^{\prime} 14^{\prime \prime}$ & 4777 & A & Rural & $4522 / 11,527$ & $2749 / 5824$ & $295 / 296$ \\
\hline Copetonas & Co & S $38^{\circ} 43^{\prime} 32^{\prime \prime}$ W $60^{\circ} 29^{\prime} 33^{\prime \prime}$ & 1017 & A & Rural & $217 / 2941$ & $74 / 13$ & $9.3 / 1.5$ \\
\hline Rauch 1 & Ra1 & S $36^{\circ} 49^{\prime} 52^{\prime \prime}$ W $59^{\circ} 16^{\prime} 43^{\prime \prime}$ & 15,176 & A & Urban cluster & $549 / 1625$ & $16 / 19$ & $1.1 / 2.2$ \\
\hline Rauch 2 & $\mathrm{Ra} 2$ & S $36^{\circ} 49^{\prime} 52^{\prime \prime}$ W $59^{\circ} 16^{\prime} 43^{\prime \prime}$ & 15,176 & A & Urban cluster & $549 / \mathrm{NA}$ & $140 / \mathrm{NA}$ & $10 / \mathrm{NA}$ \\
\hline San Antonio de Areco & SAA & S $34^{\circ} 14^{\prime} 25^{\prime \prime}$ W $59^{\circ} 29^{\prime} 45^{\prime \prime}$ & 23,138 & A & Urban cluster & $752 / 373$ & $114 / 14$ & $8.7 / 1.47$ \\
\hline Bolivar city & $\mathrm{BoC}$ & $\mathrm{S} 36^{\circ} 13^{\prime} 35^{\prime \prime} \mathrm{W} 61^{\circ} 06^{\prime} 28^{\prime \prime}$ & 26,242 & A & Urban cluster & NA/525 & $\mathrm{NA} / 48$ & NA/5.00 \\
\hline Saladillo city & $\mathrm{SaC}$ & $\mathrm{S} 35^{\circ} 38^{\prime} 58^{\prime \prime} \mathrm{W} 59^{\circ} 47^{\prime} 07^{\prime \prime}$ & 26,763 & A & Urban cluster & $671 / 3301$ & $54 / 41$ & $5.7 / 2.7$ \\
\hline Olmos 1 & Ol1 & $\mathrm{S} 35^{\circ} 01^{\prime} 04^{\prime \prime} \mathrm{W} 58^{\circ} 02^{\prime} 10^{\prime \prime}$ & 19,000 & $\mathrm{H}$ & Urban cluster & $1417 / 1390$ & $109 / 24$ & $11 / 2.3$ \\
\hline Olmos 2 & $\mathrm{Ol} 2$ & $\mathrm{~S} 35^{\circ} 01^{\prime} 04^{\prime \prime} \mathrm{W} 58^{\circ} 02^{\prime} 10^{\prime \prime}$ & 19,000 & $\mathrm{H}$ & Urban cluster & $713 / 1792$ & $69 / 160$ & $7.3 / 12$ \\
\hline Pergamino & $\mathrm{Pe}$ & S $33^{\circ} 54^{\prime} 04^{\prime \prime} \mathrm{W} 60^{\circ} 35^{\prime} 33^{\prime \prime}$ & 104,590 & $\mathrm{~A} / \mathrm{I}$ & Urbanized area & 8319/NA & 760/NA & $90 / \mathrm{NA}$ \\
\hline San Nicolas & SN & $\mathrm{S} 34^{\circ} 06^{\prime} 22^{\prime \prime} \mathrm{W} 59^{\circ} 00^{\prime} 03^{\prime \prime}$ & 143,557 & $\mathrm{~A} / \mathrm{I}$ & Urbanized area & $529 / 1311$ & $63 / 12$ & $6.3 / 1.2$ \\
\hline Great Buenos Aires & GBA & S $34^{\circ} 46^{\prime} 12^{\prime \prime}$ W $58^{\circ} 15^{\prime} 36^{\prime \prime}$ & $1,300,000$ & I & Metropolitan & $13,050 \pm 4583$ & $2405 \pm 1269$ & $108 \pm 47$ \\
\hline Florencio Varela & Va & $\mathrm{S} 34^{\circ} 50^{\prime} 25^{\prime \prime} \mathrm{W} 58^{\circ} 14^{\prime} 31^{\prime \prime}$ & $1,300,000$ & $\mathrm{I} / \mathrm{H}$ & Metropolitan & $7640 / 12,673$ & $624 / 285$ & $88 / 19$ \\
\hline
\end{tabular}

A: agricultural.

$\mathrm{I}$ : industrial.

H: horticultural.

NA: not analyzed.

of about $1 \mathrm{~mL}$ and $20 \mathrm{uL}$ of n-nonane (keeper) were introduced, and it was concentrated by gentle stream of dry nitrogen to about $20 \mu \mathrm{L}$, spiked with isotopic labeled internal standard (ISS 1613; Wellington
Laboratories Inc.) and analyzed by high resolution gas chromatography (Agilent 7890) coupled to high resolution mass spectrometry (Autospect Micromass). The mass spectrometer was operated using

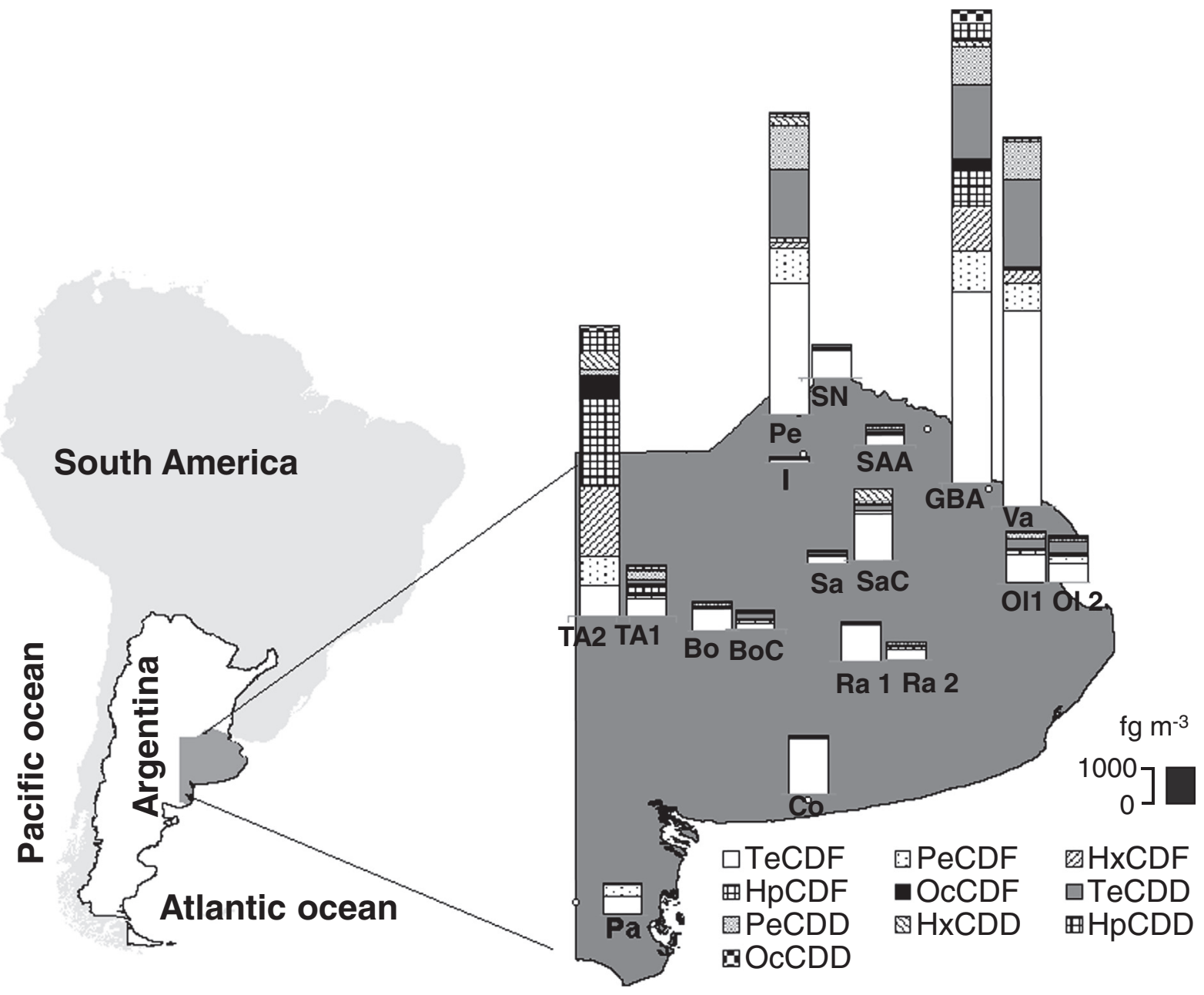

Fig. 1. Average airborne $\sum_{4-8} \mathrm{PCDD} / \mathrm{F}$ concentrations in Buenos Aires Province, Argentina. 
positive electron ionization at mass resolution of 10,000 and the two most abundant ions in the cluster were monitored. Detailed analytical information is included in the Supplementary data (Table S1 and S2).

The detection limits (3:1 signal:noise) ranged between 0.8 and $6.0 \mathrm{fg} \mathrm{m}^{-3}$ for tetra to octa PCDD/F (Table S1). Field and procedural blanks analyzed for every batch of ten samples indicated in all cases below-detection limit concentrations. Recovery efficiency ranged from 50 to $82 \%$ for the different congeners (average: $56 \pm 9 \%$ ). Five samples with lower recovery efficiency $(<50 \%)$ were discarded (NA; Table 1$)$. Seventeen 2378 substituted PCDD/F congeners were quantitated and reported individually and as total $\left(\sum_{17} \mathrm{PCDD} / \mathrm{F}\right)$ and as toxic equivalent concentrations (TEQs) using WHO equivalent factors (TEFs; Van den Berg et al., 2006). Additionally, homologous groups were quantified by summing all isomers identified at each level of chlorination (TeCDD, PeCDD, HxCDD, HpCDD, OCDD, TeCDF, PeCDF, HxCDF, HpCDF, OCDF) and reported including both 2378 -substituted and non-substituted isomers $\left(\sum_{4-8} \mathrm{PCDD} / \mathrm{F}\right)$.

Statistical analyses were performed with XLSTAT 2014 software package; ANOVA and the Tukey test were used for sample comparison at a significance level of $\mathrm{P}<0.05$. For calculations, non-detected chemicals were considered to be one half of the respective detection limits.

\section{Results and discussion}

\subsection{Total air concentrations}

PCDD/F airborne concentrations ( $\sum_{17} \mathrm{PCDD} / \mathrm{F}:$ 6-5824, mean: $632 \pm 1317 \mathrm{fg} \mathrm{m}^{-3}$; TEQ: 0.71-296, $39 \pm 76 \mathrm{fg} \mathrm{TEQ}^{-3}$; $\sum_{4-8}$ PCDD/F: $15-19690$, mean: $3578 \pm 4902$ fg m$^{-3}$; Table 1) are highly variable and generally lower than previous reports for Latin American (9-678 fg TEQ $\mathrm{m}^{-3}$; mean: $137 \mathrm{fg} \mathrm{TEQ}^{-3}$ ) and African countries (18-532; mean 147 fg TEQ m ${ }^{-3}$; Bogdal et al., 2013), and for Caribbean and Latin American cities (0.7-43 fg TEQ m ${ }^{-3}$; Schuster et al., 2015). Our data are comparable to urban air PCDD/F measurements obtained by active sampling in Mexico (0.6-410 fg; $67 \pm$ 137 fg TEQ $\mathrm{m}^{-3}$; Cardenas et al., 2011) and South Korea (ND-617; 28 fg TEQ $\mathrm{m}^{-3}$; Shin et al., 2011).

This general comparison is biased by the dependence of PCDD/F emissions/concentrations on the type and scale of urban agglomerations. A positive relationship between atmospheric pollutants and population has been demonstrated for polycyclic aromatic hydrocarbons (Hafner et al., 2005; McDonough et al., 2014), polychlorinated biphenyls (Sun et al., 2007), polybrominated biphenyl ethers (Venier and Hites, 2008) and PCDD/F (Venier et al., 2009). The exponents of the power law functions fitted to these regressions range from 0.30 to 0.60 (PAH: 0.40-0.60; PCB: 0.35; PBDE: 0.35; PCDD/F: 0.30), indicating a 23 to $52 \%$ increase in air concentrations when population doubles. In a study of PCDD/F in coastal sites of Laurentian Great Lakes, Venier et al. (2009) report a positive Log-Log relationship between population and $\Sigma_{17}$ PCDD/F concentration ( $\mathrm{p}<0.0001$; slope: $0.30 \pm 0.04$; author's personal communication). Our data also show a direct relationship between Log population and $\log \sum_{17} \mathrm{PCDD} / \mathrm{F}$ air concentrations with a significant two order of magnitude increase from rural areas (excluding an outlier peak TA2) to urban-industrial clusters ( $p<0.0001$; Fig. 2 ). The slope is in the high range of reported values $(0.57 \pm 0.10 ; p<0.0001)$ reflecting the significant role of large urban and industrialized centers as PCDD/F sources. Additional factors such as environmental conditions (i.e. temperature), economic activity, pollution regulation measures, and energy consumption patterns are also important drivers of PCDD/ F pollution and may explain slope differences (Hafner et al., 2005).

According to size-population classification (excluding TA2 outlier), our rural and urban cluster mean values are one order of magnitude lower than urbanized and metropolitan sites $(3.0 \pm 2.7 / 5.4 \pm 4.0 \mathrm{Vs}$. $33 \pm 50 / 90 \pm 51 \mathrm{fg} \mathrm{TEQ} \mathrm{m}^{-3}$, respectively). Buenos Aires rural concentrations are lower than those reported for other rural areas in the

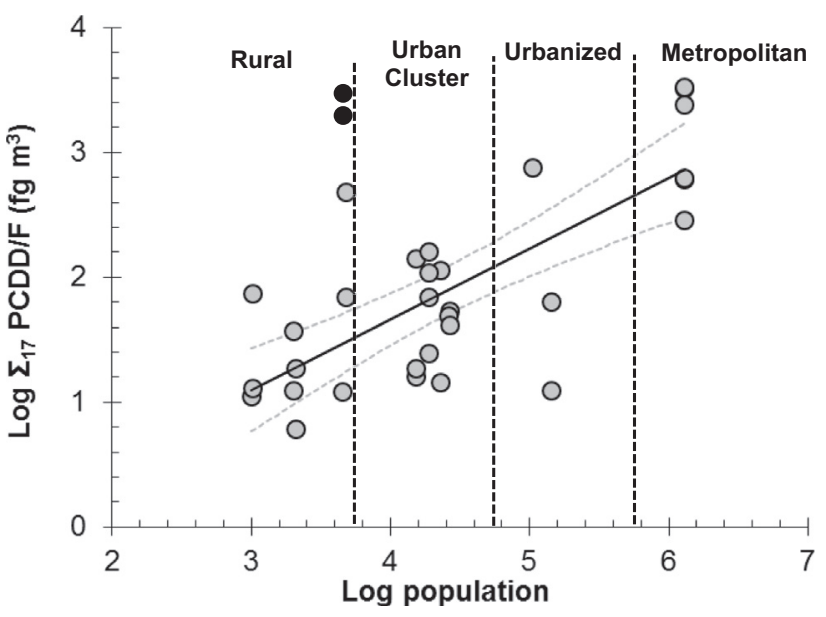

Fig. 2. Airborne $\sum_{17} \mathrm{PCDD} / \mathrm{F}$ concentrations versus population at each site (Log $\Sigma_{17}$ PCDDF $=0.57 \cdot$ Log Population $\left.-0.60 ; \mathrm{R}^{2}=0.56\right)$. The grey dotted lines represent the $95 \%$ confidence limits. The rural Outlier indicated by filled circles was excluded from the calculations.

Northern Hemisphere reflecting the lower anthropogenic impact of the less industrialized Southern Hemisphere (Lohmann et al., 2001; Morales et al., 2014), i.e. rural sites from United States (10$11 \mathrm{fg}$ TEQ $\mathrm{m}^{-3}$; Cleverly et al., 2007) and background sites of Spain (11 $\mathrm{fg}$ TEQ $\mathrm{m}^{-3}$; Mari et al., 2008). On the other side, our metropolitan concentrations are comparable to PAS data from urban areas affected by incineration (51-54 fg TEQ m ${ }^{-3}$; Gao et al., 2014) or industrial sources in China ( 74 fg TEQ $\mathrm{m}^{-3}$; Li et al., 2011). The active sampling study of rural, urban and industrial sites in Catalonia Spain also yielded an order of magnitude difference between both extremes but with 3-10 times higher values than our data ( 33 to $357 \mathrm{fg} \mathrm{TEQ} \mathrm{m}^{-3}$; Abad et al., 2004), reflecting the lower anthropogenic impact at Buenos Aires.

The highest TEQ values (295-296 fg TEQ $\mathrm{m}^{-3}$ ) of the outlier TA2, located in rural area of Buenos Aires suggests a particular source. These concentrations are comparable to the values proposed by the World Health Organization as indication of a local emission source ( $300 \mathrm{fg}$ TEQ $\mathrm{m}^{-3}$; WHO, 2000). The compositional profile of these samples effectively points to the specific contribution of waste incineration (see Section 3.2).

\section{2. $P C D D / F$ composition}

\subsection{1. $P C D D / P C D F$ ratios}

$\sum_{4-8}$ Dioxins and $\sum_{4-8}$ Furans ratios can be used to approximate PCDD/F sources (Li et al., 2011). Generally, agrochemicals present relatively high and variable ratios, i.e. pentachlorophenols (2-82; Masunaga et al., 2001) or phenoxy herbicides (0.2-23; Holt et al., 2010) whereas thermal related sources normally show lower ratios $(<1)$. Consistently low ratios have been reported for ambient air near solid waste incinerators $(0.32 \pm 0.03$; Oh et al., 2001), exhaust gases from plastic combustion ( $0.26 \pm 0.10$; Katami et al., 2002), open burning of waste (0.27-0.44; Lundin et al., 2013), domestic wood and coal burning (0.36-0.50; Lee et al., 2005) and heavy duty diesel engine emissions (0.39-0.64; Ryan and Gullett, 2000). Higher, more variable ratios has been reported for metallurgical processes (0.16-1.5; Buekens et al., 2000) and industrial waste incineration (0.3-10; Ogura et al., 2001). In our study, dioxin/furan ratios are low and relatively homogeneous with no significant differences $(P>0.05)$ among rural $(0.30 \pm$ $0.20)$, urban cluster $(0.60 \pm 0.45)$, urbanized area $(0.40 \pm 0.33)$ and metropolitan area $(0.50 \pm 0.14)$, pointing a general predominance of combustion sources. 
3.2.2. $P C D D / F$ congener and homologue profiles

In spite of the recurrent non-detection of some 2378 PCDD/F congeners and some variability, PUFs show an overall congener pattern with a characteristic predominance of $1,234,678 \mathrm{HpCDF}(13 \pm 12 \%)$ and OCDD $(12 \pm 11 \%)$. Both samples from outlier TA2 exhibit a distinctive PCDD/F composition with predominance of $1,234,678 \mathrm{HpCDF}$ (23-30\%), $234,678 \mathrm{HxCDF}$ (20-19\%) and OCDF (11-18\%), similar to solid waste and hospital waste incineration profiles (Zhang et al., 2014).

The general homologue composition shows the dominance of TeCDF and TeCDD groups ( $52 \pm 23 \%$ and $13 \pm 9 \%$ of total PCDD/Fs), with decreasing proportions of higher chlorinated homologues. TeCDFs which present slight differences between rural (60 $\pm 19 \%)$ and urban sites ( $43 \pm 12 \%$ ), have been reported as dominant homologues in most combustion emissions, such as biomass, wood, coal waste and diesel engine (Lee et al., 2005; Gullett et al., 2008; Laroo et al., 2011; Lundin et al., 2013). The homologue profile of outlier TA2 exhibits a contrasting pattern with a clear predominance of HpCDF (29-33\%) and HxCDF (16-27\%).

In order to more clearly identify potential contributing sources, independent principal component analysis (PCA) were performed with the contribution of the seventeen 2378 substituted congeners and PCDD/F homologues in each sample $(n=33)$. To identify source contributions, a total of 11 literature emission profiles were included in the PCA, i.e. three emissions of municipal solid waste incineration (MSWI; Oh et al., 2001; Ogura et al., 2001; Zhang et al., 2014), one profile of open burning of waste (OB; Lundin et al., 2013), two emissions of biomass burning (BB; Gullett and Touati, 2003), two profiles of chemical and refinery industry (Industrial; Oh et al., 2001), and three diesel emissions (Diesel; Oehme et al., 2001; Laroo et al., 2011).

In the case of 2378 congeners, the first two components (PC1 and PC2) explain $45 \%$ of the total variability (Fig. 3, upper). PC1 (30\%) is basically determined by $123,678-H x C D D, 123,789-H x C D D$ and $123,478-$

- Metropolitan oUrban cluster o Urbanized area oRural $*$ Sources

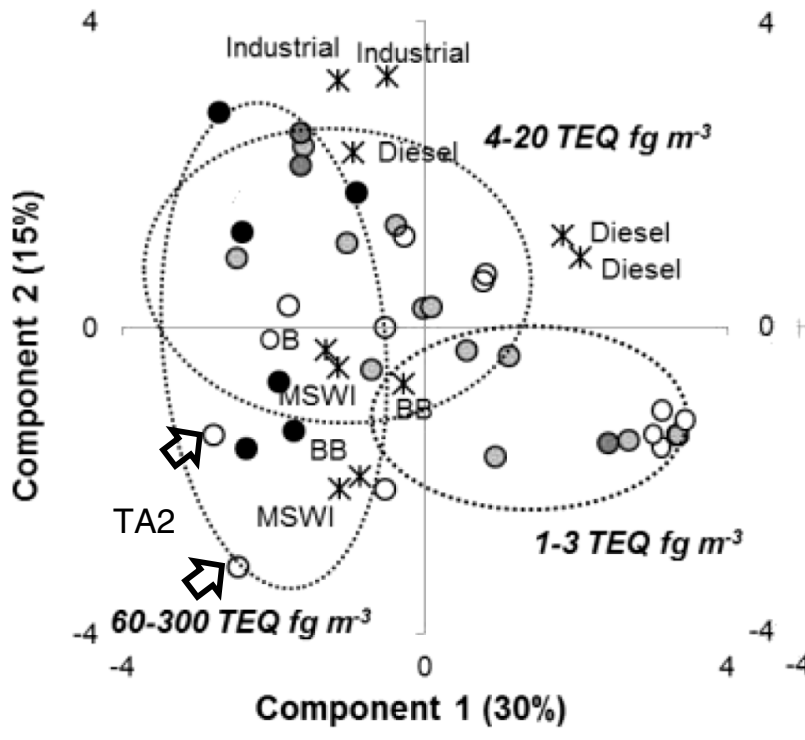

4
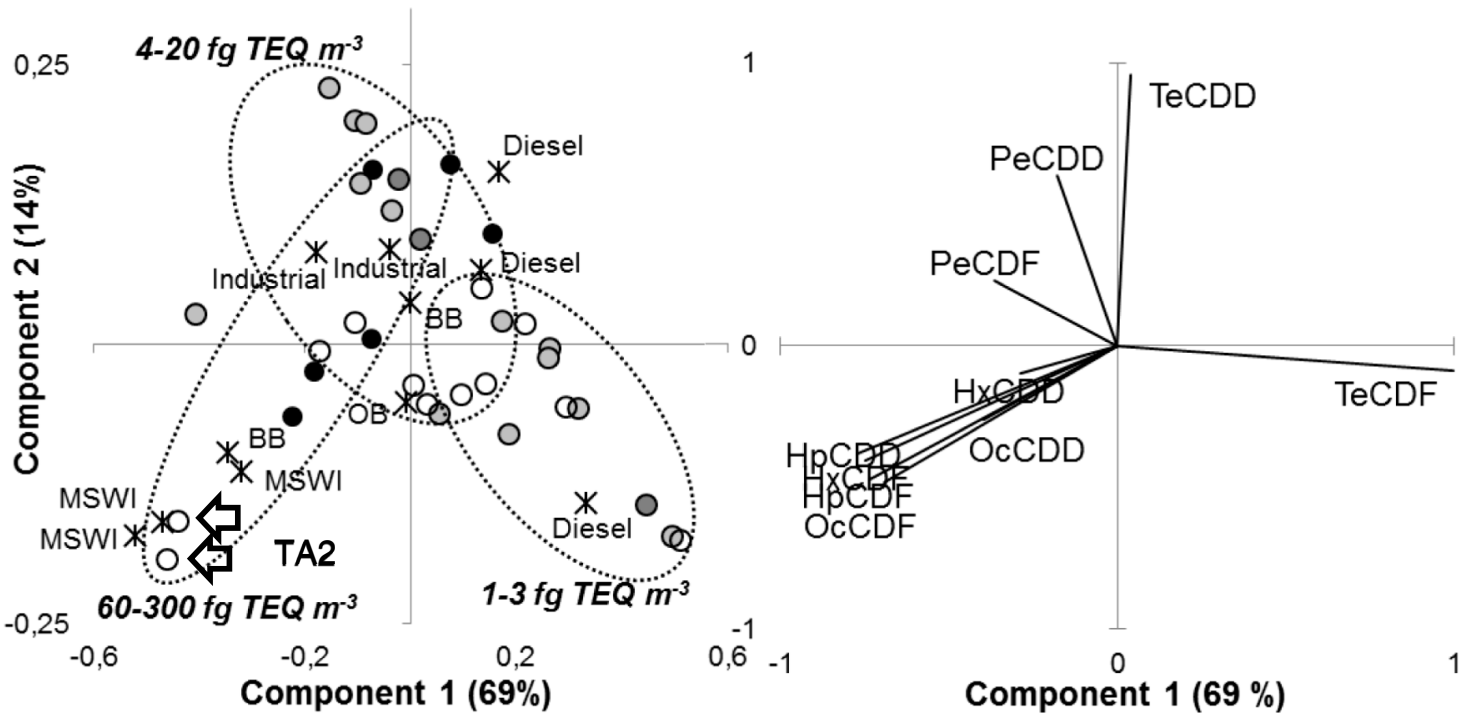

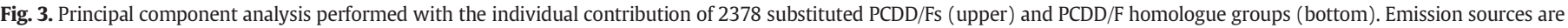

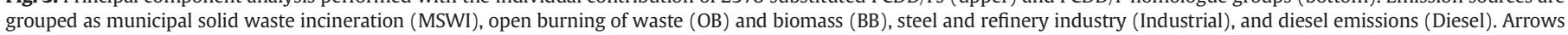
indicate the rural outlier (TA2). 
HxCDD (+ PC1), and 1,234,678 HpCDF (-PC1), whereas PC2 (15\%) has a prevailing contribution of 2378-TeCDF and 12,378-PeCDF (+ PC2), and OCDF and 1,234,678-HpCDD ( - PC2). Source profiles form three distinctive clusters: to the lower-left side MSWI, OB and BB; to the upper-left side industrial emissions; and to the upper-right side, two profiles of diesel engine emissions. Our rural samples are distributed between diesel and MSWI/OB/BB clusters, whereas metropolitan samples spread close to industrial and MSWI/OB/BB clusters. The highest TEQ outlier (TA2) plots close to MSWI/OB/BB sources. The distribution of TEQ concentrations along the overall separation scheme of the score plot does not show a clear pattern, but the highest TEQ concentrations seem to be linked with open waste burning, biomass burning and MSWI.

In the homologue group PCA (Fig. 3, lower), PC1 and PC2 account for a higher 69 and $14 \%$ of the total variability, respectively. PC1 is basically defined by the opposing contribution of TeCDF, (+ PC1), and HxCDF, HpCDF, and OCDF ( $-P C 1)$, whereas PC2 has a dominant contribution of TeCDD and PeCDF ( + PC2). Specific sources are distributed in four main groups: MSWI plot in the lower-left; diesel engine emissions spread on the right side; industrial sources in the upper-left, and OB and BB in an intermediate-left position. Rural samples spread mostly in the lower right side, closer to diesel exhaust profiles. Metropolitan samples are distributed between diesel, BB and OB and industrial emissions. Two rural samples from a site located $5 \mathrm{~km}$ away of the highest TEQ outlier (TA2) plot in the left side, whereas TA2 samples plot in the lower-left side close to MSWI. Further investigation of this site revealed that $20 \mathrm{~km}$ way from site TA2, obsolete incinerators at Trenque Lauquen city produced recurrent complains from nearby populations. The homologue PCA shows a better separation pattern of samples according to composition and TEQ concentrations. Air samples with $<-$ $3 \mathrm{fg}$ TEQ $\mathrm{m}^{-3}$ plot in the lower-right (close to the diesel pattern), the 5-20 fg TEQ $\mathrm{m}^{-3}$ range concentration samples plot in the upper-left (related to industrial, biomass burning and open waste burning) whereas concentrations higher than $60 \mathrm{fg}$ TEQ $\mathrm{m}^{-3}$ plot in the upper left to the lower-left side (industrial, biomass burning and MSWI).

The comparative evaluation of PCA results from different levels of $\mathrm{PCDD} / \mathrm{F}$ monitoring information shows that homologue analysis performs better to explain the overall compositional variability of the data compared to the 17 congeners ( 83 Vs. $45 \%$ variability, respectively). In addition, clustering of samples in the homologue PCA more precisely linked air patterns with specific source signatures and also showed a clearer relationship between sources and TEQ concentrations.

In summary, Buenos Aires airborne PCDD/F profiles are influenced by different emission sources, with a general contribution of unregulated sources such as traffic, biomass or waste burning. In rural sites, PCA clearly identify diesel emissions as the principal contributor whereas in urban areas prevail the influence of industrial and open burning emissions. The homologue patterns associated to industry and MSWI emissions show the highest TEQ concentrations, especially in the rural outlier TA2 which present a clear MSWI signature.

\section{Appendix A. Supplementary data}

Supplementary data to this article can be found online at http://dx. doi.org/10.1016/j.scitotenv.2016.07.126.

\section{References}

Abad, E., Caixach, J., Rivera, J., Gustems, L., Massagué, G., Puig, O., 2004. Temporal trends of PCDDs/PCDFs in ambient air in Catalonia (Spain). Sci. Total Environ. 334-335, 279-285.

Astoviza, M., Cappelletti, N., Bilos, C., Migoya, C., Colombo, J.C., 2016. Massive airborne Endosulfan inputs related to intensive agriculture in Argentina's Pampa. Chemosphere $144,1459-1466$

Bogdal, C., Scheringer, M., Abad, E., Abalos, M., Van Bavel, B., Hagberg, J., Fiedler, H., 2013. Worldwide distribution of persistent organic pollutants in air, including results of ai monitoring by passive air sampling in five continents. Trends Anal. Chem. 46 $150-161$.
Buekens, A., Cornelis, E., Huang, H., Dewettinck, T., 2000. Fingerprints of dioxin from thermal industrial processes. Chemosphere 40 (9-11), 1021-1024.

Cardenas, B., Ferrario, J., Byrne, C., Basaldud, R., Benitez, S., Wöhrnschimmel, H., Ortinez, A., Angeles, F., Galindo, I., Gold, G., et al., 2011. Baseline ambient concentrations of dioxins and furans in Mexico : 2008-2010 operation of the Mexican dioxin air monitoring network (MDAMN). Organohalogen Compd. 73, 2008-2010.

Center for International Earth Science Information Network - CIESIN - Columbia University, United Nations Food and Agriculture Programme - FAO, and Centro Internacional de Agricultura Tropical - CIAT, 2005-. Gridded Population of the World, Version 3 (GPWv3): Population Count Grid. Palisades. NASA Socioeconomic Data and Applications Center (SEDAC), NY http://dx.doi.org/10.7927/H4639MPP (Accessed: August, 2015).

Cleverly, D., Ferrario, J., Byrne, C., Riggs, K., Joseph, D., Hartford, P., 2007. A general indication of the contemporary background levels of PCDDs, PCDFs, and coplanar PCBs in the ambient air over rural and remote areas of the United States. Environ. Sci. Technol. 41, 1537-1544.

Cortés, J., González, C.M., Morales, L., Abalos, M., Abad, E., Aristizábal, B.H., 2014. PCDD/ PCDF and Dl-PCB in the ambient air of a tropical Andean City: passive and active sampling measurements near industrial and vehicular pollution sources. Sci. Total Environ. 491-492, 67-74.

De Assunção, J.V., Pesquero, C.R., Bruns, R.E., Carvalho, L.R.F., 2005. Dioxins and furans in the atmosphere of São Paulo City, Brazil. Chemosphere 58 (10), 1391-1398.

Gao, L., Zhang, Q., Liu, L., Li, C., Wang, Y., 2014. Determined using polyurethane foam passive air samplers. Chemosphere 114, 317-326.

Gullett, B., Touati, A., 2003. PCDD/F emissions from burning wheat and rice field residue. Atmos. Environ. 37 (35), 4893-4899.

Gullett, B., Touati, A., Oudejans, L., 2008. PCDD/F and aromatic emissions from simulated Forest and grassland fires. Atmos. Environ. 42 (34), 7997-8006.

Hafner, W.D., Hites, R., Carlson, D.L., 2005. Influence of local population on atmospheric polycyclic aromatic hydrocarbon concentrations. Environ. Sci. Technol. 39 (19) 7374-7379.

Harner, T., Shoeib, M., Gouin, T., Blanchard, P., 2006. Polychlorinated naphthalenes in Great Lakes air: assessing spatial trends and combustion inputs using Puf disk passive air samplers. Environ. Sci. Technol. 40 (17), 5333-5339.

Hites, R., 2011. Dioxins: an overview and history. Environ. Sci. Technol. 45, 16-20.

Holt, E., Weber, R., Stevenson, G., Gaus, C., 2010. Polychlorinated dibenzo-p-dioxins and dibenzofurans (PCDD/Fs) impurities in pesticides: a neglected source of contemporary relevance. Environ. Sci. Technol. 44 (14), 5409-5415.

Katami, T., Yasuhara, A., Okuda, T., Shibamoto, T., 2002. Role of inorganic chlorides in formation of PCDDs, PCDFs, and coplanar PCBs from combustion of plastics, newspaper, and pulp in an incinerator. Environ. Sci. Technol. 36 (18), 3924-3927.

Klanova, J., Kohoutek, J., Hamplova, L., Urbanova, P., Holoubek, I., 2006. Passive air sampler as a tool for long-term air pollution monitoring: Part 1. Performance assessment for seasonal and spatial variations. Environ. Pollut. 144, 393-405.

Laroo, C.A., Schenk, C.R., Sanchez, L.J., McDonald, J., 2011. Emissions of PCDD/Fs, PCBs, and PAHs from a modern diesel engine equipped with catalyzed emission control systems. Environ. Sci. Technol. 45 (15), 6420-6428.

Lee, R.G.M., Coleman, P., Jones, J.L., Jones, K.C., Lohmann, R., 2005. Emission factors and importance of PCDD/Fs, PCBs, PCNs, PAHs and $\mathrm{PM}_{10}$ from the domestic burning of coal and wood in the U.K. Environ. Sci. Technol. 39 (6), 1436-1447.

Li, X., Li, Y., Zhang, Q., Wang, P., Yang, H., Jiang, G., Wei, F., 2011. Evaluation of atmospheric sources of PCDD/Fs, PCBs and PBDEs around a steel industrial complex in Northeast China using passive air samplers. Chemosphere 84 (7), 957-963.

Lohmann, R., Jurado, E., Dachs, J., Lohmann, U., Jones, K.C., 2006. Quantifying the importance of the atmospheric sink for polychlorinated dioxins and furans relative to other global loss processes. J. Geophys. Res. Atmos. 111 (21), 1-11.

Lohmann, R., Ockenden, W.A., Shears, J., Jones, K.C., 2001. Atmospheric Distribution of Polychlorinated Dibenzo-P-Dioxins, Dibenzofurans (PCDD/Fs), and NonOrtho Biphyenyls (PCBs) along a North - South Atlantic Transect. 35(20) pp. 4046-4053.

Lundin, L., Gullett, B., Carroll, W.F., Touati, A., Marklund, S., Fiedler, H., 2013. The effect of developing nations' municipal waste composition on PCDD/PCDF emissions from open burning. Atmos. Environ. 79, 433-441.

Mari, M., Schuhmacher, M., Feliubadaló, J., Domingo, J.L., 2008. Air concentrations of PCDD/Fs, PCBs and PCNs using active and passive air samplers. Chemosphere 70 (9), 1637-1643.

Masunaga, S., Takasuga, T., Nakanishi, J., 2001. Dioxin and dioxin-like PCB impurities in some Japanese agrochemical formulations. Chemosphere 44 (4), 873-885.

McDonough, C.A., Khairy, M.A., Muir, D.C.G., Lohmann, R., 2014. Significance of population centers as sources of gaseous and dissolved PAHs in the lower Great Lakes. Environ. Sci. Technol. 48, 7789-7797.

Ministerio de Economía, March 2012. Economic Overview of the Province of Buenos Aires. Website: http://www.ec.gba.gov.ar.

Molina, L., Cabes, M., Ferrero, J., Coll, M., Marti, R., Puig, F., Comellas, L., Larena, M., 2000. Separation of non-ortho polychlorinated biphenyl congeners on pre-packed carbon tubes. Application to analysis in sewage sludge and soil samples. Chemosphere 40, 921-927.

Morales, L., Dachs, J., González-Gaya, B., Hernán, G., Ábalos, M., Abad, E., 2014. Background concentrations of polychlorinated dibenzo-p-dioxins, dibenzofurans, and biphenyls in the global oceanic atmosphere. Environ. Sci. Technol. 48 (17), 10198-10207.

Oehme, M., Larssen, S., Brevik, E., 2001. Emission factors of PCDD and PCDF for road vehicles obtained by tunnel experiment. Chemosphere 23 (11-12), 1699-1708.

Ogura, I., Masunaga, S., Nakanishi, J., 2001. Atmospheric deposition of polychlorinated dibenzo-p-dioxins, polychlorinated dibenzofurans, and dioxin-like polychlorinated biphenyls in the Kanto region, Japan. Chemosphere 44 (6), 1473-1487. 
Oh, J.E., Choi, J.S., Chang, Y.S., 2001. Gas/particle partitioning of polychlorinated dibenzoP-dioxins and dibenzofurans in atmosphere; evaluation of predicting models. Atmos. Environ. 35 (24), 4125-4134.

Pozo, K., Harner, T., Shoeib, M., Urrutia, R., Barra, R., Parra, O., Focardi, S., 2004. Passivesampler derived air concentrations of persistent organic pollutants on a northsouth transect in Chile. Environ. Sci. Technol. 38 (24), 6529-6537.

Ryan, J.V., Gullett, B.K., 2000. On-road emission sampling of a heavy-duty diesel vehicle for polychlorinated dibenzo-p-dioxins and polychlorinated dibenzofurans. Environ. Sci. Technol. 34 (21), 4483-4489.

Schuster, J.K., Harner, T., Fillmann, G., Ahrens, L., Altamirano, J.C., Bastos, W.R., Castillo, L.E. Cortés, J., Fentanes, O., Gusev, A., et al., 2015. Assessing PCDD/Fs in air across Latin American countries using PUF disk passive air samplers. Environ. Sci. Technol. 49 (6), 3680-3686.

Shin, S.K., Jin, G.Z., Kim, W.I., Kim, B.H., Hwang, S.M., Hong, J.P., Park, J.S., 2011. Nationwide monitoring of atmospheric PCDD/Fs and dioxin-like PCBs in South Korea. Chemosphere 83 (10), 1339-1344.

Sun, P., Basu, I., Blanchard, P., Brice, K.A., Hites, R.A., 2007. Temporal and spatial trends of atmospheric polychlorinated biphenyl concentrations near the Great Lakes. Environ. Sci. Technol. 41 (4), 1131-1136.

UNEP, 2011. Draft revised guidance on the global monitoring plan for persistent organic pollutants. Document UNEP/POPS/COP.5/INF/27".

United States Census Bureau, 2010. Website: http://www.census.gov/geo/reference/ua/ urban-rural-2010.html.
US EPA (United States Environmental Protection Agency), 1994. Method 1613 Tetrathrough Octa-Chlorinated Dioxins and Furans by Isotope Dilution HRGC/HRMS (Washington, D.C.).

Van den Berg, M., Birnbaum, L., Bosveld, A., Brunstrom, B., Cook, P., Feeley, M., Giesy, J., Hanberg, A., Hasegawa, R., Kennedy, S., Kubiak, T., Larsen, J., Van Leeuwen, F., Liem, A., Nolt, C., Peterson, R., Poellinger, L., Safe, S., Schrenk, D., Tillitt, D., Tsykline, M., Younes, M., Warn, F., Zacharewski, T., 1998. Toxic equivalency factors (TEFs) for PCBs, PCDDs, PCDFs for humans and wildlife. Environ. Health Perspect. 106, 775-792.

Van den Berg, M., Birnbaum, L.S., Denison, M., De Vito, M., Farland, W., Feeley, M., Fiedler, H., Hakansson, H., Hanberg, A., Haws, L., et al., 2006. The 2005 World Health Organization reevaluation of human and mammalian toxic equivalency factors for dioxins and dioxin-like compounds. Toxicol. Sci. 93 (2), 223-241.

Venier, M., Hites, R., 2008. Brominated flame retardants in the Great Lakes. Environ. Sci. Technol. 42, 4745-4751.

Venier, M., Ferrario, J., Hites, R., 2009. Polychlorinated dibenzo-p-dioxins and dibenzofurans in the atmosphere around the Great Lakes. Environ. Sci. Technol. 43 (4), 1036-1041.

WHO regional publication, 2000. European Series; N²9. Air Quality Guidelines for Europe. second ed.

Zhang, M., Zhang, S., Zhang, Z., Xu, Z., Feng, G., Ren, M., 2014. Influence of a municipal solid waste incinerator on ambient air PCDD/F levels: a comparison of running and non-running periods. Sci. Total Environ. 491-492, 34-41. 